\title{
Trends of cross-border mobility of physicians and nurses between Portugal and Spain
}

\author{
Claudia Leone ${ }^{1 *}$, Cláudia Conceição ${ }^{2,3}$ and Gilles Dussault ${ }^{1}$
}

\begin{abstract}
Context: Health workforce cross-border mobility has an impact not only on individual health workers, but also on how health services are organized, planned, and delivered. This paper presents the results of a study of current mobility trends of health professionals along the borders between Portugal and Spain. The objective was to describe the profile of mobile physicians and nurses; to elicit the opinions of employers on mobility factors; to describe incentive policies to retain or attract health professionals; and to collect and analyse employers' opinions on the impact of this mobility on their health services.
\end{abstract}

Methods: Phone interviews of key informants were used to collect relevant data. The interviews were conducted during December 2010 and January 2011 in health organizations along the border of the two countries. In Portugal and Spain, four and 13 organizations were selected, respectively. Interviews were obtained in all the Portuguese organizations and in four of the Spanish organizations.

Results: Findings suggest that cross-border mobility between the two countries has decreased. From Spain to Portugal, mobility trends are mainly of physicians who seek professional development in the form of specialization, the availability of positions, better salaries, and the perceived good living conditions. The mobility of nurses lasted until 2008, when reforms improved working conditions in Spain and contributed to reversing the flow. Since then, there has been an increase of Portuguese nurses going to Spain seeking better working conditions or simply a job. Portuguese nurses as well as Spanish physicians are well considered in terms of professionalism and qualifications by their Spanish and Portuguese hosts, respectively.

Conclusions: There is a deficit of valid data on the health workforce in general. The present study allowed further exploration of the reality of the mobility trends between Portugal and Spain. At present, the mobility trends are mainly of Spanish physicians to Portugal and Portuguese nurses to Spain. There is a consensus on both sides of the border that the benefits of migratory flows are much greater than the limited problems (for example, language and salary differences) that they may bring.

Keywords: Cross-border mobility, Health workers, Portugal, Spain

This paper presents the results of a study that documented current trends of mobility of health professionals along the borders of Portugal and Spain which share a border of $1,215 \mathrm{~km}$ from North to South. The specific objectives are to characterize the profile of health professionals who cross the border for working purposes; to elicit the perceptions of employers on mobility factors; to describe the recruitment processes of health professionals in selected health organizations

\footnotetext{
* Correspondence: claudia.leone@ihmt.unl.pt

'Institute of Hygiene and Tropical Medicine, Nova University, Lisbon, Portugal Full list of author information is available at the end of the article
}

along the border; to describe incentive policies to attract or retain health professionals and to collect and analyse employers' opinions on the impact of this phenomenon on health services systems.

\section{Context}

Portugal's National Health Service (NHS) offers universal coverage, is comprehensive, and is predominantly financed through general taxation. The NHS is the main provider of healthcare for which user fees are applicable to persons above a certain income level, but there is a growing private sector, as well as public-private partnerships in the

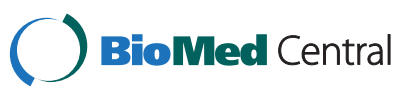


hospital sector. The management of the NHS mostly takes place at central and regional levels. The Ministry of Health is responsible for the definition, implementation, and monitoring of national health policy objectives, for the strategic management of funds, and employs service providers. There are five Regional Health Administrations (RHA), which have the mission of ensuring access to quality healthcare to the population under their jurisdiction and to implement the National Health Policy. Under the RHAs, which are directly accountable to the Ministry of Health, there are local health units (unidades locais de saúde), groups of health centers (ACES; agrupamentos de centros de saúde), and hospital centers (centros hospitalares). Local Health Units are groupings of health centers and hospitals, usually composed of two or more previously autonomous organizations, functioning under a common management structure. Seventy-three groups of primary care health centers have been created in 2009 to improve efficiency through better coordination and sharing of resources. In 2012, the Ministry of Health has announced that the number of ACES would be reduced to 46, as part of the austerity program which the Government of Portugal is conducting. The creation of more local structures was presented as an effort towards decentralization, but in the absence of financial autonomy, the dependency on RHAs remains strong. Hospital centers are groupings of at least two hospitals located in the same region (although frequently involving hospitals in different towns). From those hospitals most of them acquired, in the last 10 years, a legal status of financial and administrative autonomy (EPE, Entidades Públicas Empresariais Public Autonomous Organizations). Only Local Health Units and EPE hospitals or Hospital Centers have the autonomy to directly hire health personnel [1].

The main employer of health professionals is the NHS (Tables 1 and 2) [1,2]. The private sector is growing, and is becoming an important employer, with an undetermined number of professionals working in both the public and the private sectors. There is no monitoring of dual employment nor of mobility of health professionals $[1,3]$.
In Spain there is also a NHS providing universal coverage, almost fully funded from taxes and predominantly within the public sector. Access to services is free of charge at the point of delivery [8]. Planning and the delivery of health services are done at the level of the Autonomous Communities. There are 17 regional ministries or departments of health, with jurisdiction over the organization and delivery of health services within their territory. Health expenditure is mainly determined by these regional administrations, which are accountable only to their regional parliament and are not hierarchically linked to the national level [8].

The national Ministry of Health and Social Policy has only the authority over legislation on pharmaceuticals and is the guarantor of the equitable functioning of health services across the country. The Ministry became in 2009 the national authority in the field of social and dependency care [9]. There are also local authorities in some provinces and municipalities that have the competency over sanitation and which collaborate in health services provision and direct management of 'residual' public health and community services [8].

\section{The medical and nursing workforce}

In Spain [10] and in Portugal [11-14] there is a deficit of updated and valid data on the health workforce in general. Multiple sources offer partial views of reality, as illustrated by the list of sources of data available in Portugal (Table 3). In the next two sections, data available will be presented and discussed.

\section{Portugal}

In 2010, the number of physicians per 1,000 population in Portugal was above the EU27 average (3.8 in Portugal; 3.4 EU27 average). The density of nurses was well below the EU27 average (5.7 per 1,000 population versus the EU27 average of 7.9); Portugal has one of the lowest ratios of nurses to physicians in the EU (1.5 versus 2.5 in EU27) [1].

Foreign physicians and nurses represent a small proportion of the total of professionals working in the

Table 1 Number of physicians in Portugal, 2003, 2007, 2008, 2009, and 2010

\begin{tabular}{|c|c|c|c|c|c|}
\hline Physicians ( $n$ ) & 2003 & 2007 & 2008 & 2009 & 2010 \\
\hline Total registered & 34.981 & 38.399 & 39.470 & $40.664[4]$ & $42.031[4]$ \\
\hline Foreign physicians registered & 2.987 & 3.656 & 4.397 & $3.842[4]$ & $3.937[4]$ \\
\hline Spanish physicians registered & $1.757[5]$ & $1.971[5]$ & NA & NA & NA \\
\hline Total physicians in NHS & $24.444[2]$ & $24.831[2]$ & $25.106[2]$ & $23.007[6]$ & $23.324[6]$ \\
\hline Spanish physicians in NHS & $1.090[2]$ & $913[2]$ & 799 [2] & $681[7]$ & $696[7]$ \\
\hline
\end{tabular}

Detailed description: this table shows the number of physicians registered in Portugal, total, foreign and Spanish, total and Spanish physicians working in the Portuguese NHS, 2003, 2007, 2008, 2009, and 2010.

NA, not available; NHS, National Health Service.

Source: Medical Council and references number [2,4-7]. 
Table 2 Number of nurses in Portugal, 2003, 2007, 2008, 2010, and 2011

\begin{tabular}{|c|c|c|c|c|c|}
\hline Nurses (n) & 2003 & 2007 & 2008 & 2010 & 2011 \\
\hline Total registered & 43.978 & 50.955 & 56.859 & 62.566 & 64.535 \\
\hline Foreign nurses registered & 2.298 & 2.135 & 2.037 & 2.005 & 1958 \\
\hline Spanish nurses registered & 1.815 & 1.362 & 1.232 & 1.154 & 1133 \\
\hline Total nurses in NHS & $35.310[2]$ & $38.260[2]$ & $38.561[2]$ & $39.522[6]$ & $39.686[6]$ \\
\hline Spanish nurses in NHS & $1.427[2]$ & $413[2]$ & 319 [2] & $310[7]$ & NA \\
\hline
\end{tabular}

Detailed description: this table shows the number of nurses registered in Portugal, total, foreign and Spanish, total and Spanish nurses working in the Portuguese NHS, 2003, 2007, 2008 2010, and 2011.

NA, not available; NHS, National Health Service.

Sources: Nursing Council and references number $[2,6,7]$.

Portuguese NHS: $6.85 \%$ of physicians and $1.19 \%$ of nurses in 2008 [2]. There has been an increase of foreign workers from 313 in 1994 to a peak of 4.490 in 2004 $[14,15]$. Until 1999, the main source of foreign health workers was the five African countries with Portuguese as official language (former Portuguese colonies until 1975), but after 2002 Spain became the main source country. Last available data show that $46 \%(n=799)$ of foreign physicians and $49 \%(n=319)$ of foreign nurses were from Spain $[14,15]$ (Tables 1 and 2).

\section{Spain}

In Spain, the number of all categories of health professionals per 1,000 population has increased steadily over time, principally nurses, dentists, or pharmacists, whereas the physicians/population ratio has grown more slowly. In 2010, there were 3.8 registered physicians per 1,000 as in Portugal, and 4.9 nurses, a figure well below EU27 average [16]. National figures differ slightly from those provided by the World Health Organization (WHO) or even by regional authorities due to the absence of a central registry of health professionals [8]. There is no national data registry of health professionals but rather 17 regional registries. The National Health Service Human Resources Commission has the task of planning for the needs of the NHS [17]. Various autonomous communities have started to hire doctors trained abroad, mainly from Latin America, in certain specialties for which they expect a shortfall, but no figures are available.

The evolution of the total number of Spanish physicians and nurses in Portugal is related to the evolution of Spanish workers mobility (Figures 1 and 2). The highest peak for physicians was achieved in 2005 (1,140 physicians, Figure 1) and in 2003 for nurses $(1,427$, Figure 2 and Table 2).

\section{Methods}

Information on the mobility of professionals was collected by telephone interviews of key informants. This method was selected to minimize time and financial costs due to distances between health units along the border. Key informants were human resources managers or their representatives.

The study units were health organizations located along the border between the two countries. The distances between the cities from both sides of the border are typically around $100 \mathrm{~km}$ (for example, $101 \mathrm{~km}$ from Badajoz to Évora, $112 \mathrm{~km}$ from Huelva to Faro).

The map of Hospitals EPE produced by the Portuguese Ministry of Health was used to identify NHS hospitals located in the Portuguese regions bordering Spain. In the case of Portugal we chose hospitals EPE (Entidades Públicas Empresariais - Public Autonomous Organizations) [18] because they have the autonomy to directly hire health personnel. All the organizations in the border region were included: two were Local Health Units and two were Hospital Centers, each composed of two or more organizations sharing the same administration and human resources department (Table 4).

The selection in Spain was based on the Hospital National Catalogue, which publishes a list of public and private (for-profit and not-for-profit) hospitals [21]. The 26 health units, out of a total of 87, located in the Autonomous Communities bordering Portugal (Galicia, Castilla y León, Estremadura, and Andalucía) were selected. Telephone contacts were made to identify hospitals with $>20$ beds and which employed Portuguese health professionals: the final list included 13 units. The excluded units include a home for the elderly, two which did not meet the number of beds criterion, two which shared the same administration and human resources department of selected hospitals, and eight with no Portuguese health professionals on their staff.

Further telephone contacts were made to identify the Human Resources manager and to request an interview. Emails were sent with information on the project and with the interview schedule. The correspondence with Spain was in Spanish.

An interview schedule was designed to cover the following topics: (1) characterization of the population of health professionals from the other country working in the organization (categories of professionals, specialties, whether they live in the country of work or not, 
Table 3 Information sources: characteristics and limitations

\begin{tabular}{|c|c|c|}
\hline \multicolumn{2}{|l|}{ Information sources } & Comments \\
\hline \multirow[t]{2}{*}{ Medical Council (Ordem dos Médicos) } & Name & \multirow{2}{*}{$\begin{array}{l}\text { - Only demographic characteristics and geographical } \\
\text { distribution based on the area of residence. }\end{array}$} \\
\hline & Residence & \\
\hline \multirow[t]{4}{*}{ Registration } & Age & \\
\hline & Year of graduation & \multirow{3}{*}{$\begin{array}{l}\text { - Lack of information on register updating as a result } \\
\text { of long-term absence, death, or retirement. }\end{array}$} \\
\hline & School of graduation & \\
\hline & Specialization (most of the times) & \\
\hline \multirow[t]{2}{*}{ Nursing Council (Ordem dos Enfermeiros) } & Name & \multirow{2}{*}{$\begin{array}{l}\text { - Demographic characteristics and geographical } \\
\text { distribution based on place of work. }\end{array}$} \\
\hline & Address & \\
\hline \multirow[t]{5}{*}{ Registration } & Age & \multirow{5}{*}{$\begin{array}{l}\text { - Lack of information on register updating as a result } \\
\text { of long-term absence, death, or retirement. }\end{array}$} \\
\hline & Year of graduation & \\
\hline & School of graduation & \\
\hline & Place of work & \\
\hline & Specialization & \\
\hline \multirow[t]{2}{*}{ Dental Council (Ordem dos Médicos dentistas) } & Name & \multirow{2}{*}{$\begin{array}{l}\text { - Demographic characteristics and geographical } \\
\text { distribution based on the area of residence and work. }\end{array}$} \\
\hline & Address & \\
\hline \multirow[t]{6}{*}{ Registration } & Age & \\
\hline & Year of graduation & \multirow{5}{*}{$\begin{array}{l}\text { - Lack of information on register updating as a result } \\
\text { of long-term absence, death, or retirement. }\end{array}$} \\
\hline & School of graduation & \\
\hline & Place of work & \\
\hline & Residence & \\
\hline & Nationality & \\
\hline \multirow[t]{2}{*}{ Pharmacy Council (Ordem dos Farmacêuticos) } & Name & \multirow{2}{*}{$\begin{array}{l}\text { - Demographic characteristics and geographical } \\
\text { distribution based on the area of residence. }\end{array}$} \\
\hline & Address & \\
\hline \multirow[t]{3}{*}{ Registration } & Age & \multirow{3}{*}{$\begin{array}{l}\text { - Lack of information on register updating as a result } \\
\text { of long-term absence, death, or retirement. }\end{array}$} \\
\hline & Sex & \\
\hline & Professional area & \\
\hline
\end{tabular}

INE, Statistics Portugal

National population census

INE, Statistics Portugal

Health workforce statistics

Central Administration of the National Health Service, Ministry of Health (ACSS Administração Central do Sistema de Saúde)

Health personnel database
Ministry of Labour and Social Affairs - Strategy
and planning office (Ministério do Trabalho
e da Segurança Social - Gabinete de estratégia
e planeamento)
e da Segurança Social - Gabinete de estratégia e planeamento)
- The national population censuses provide the broadest picture available of the workforce in general and of the healthcare workforce

- Last one in 2011.

- INE uses the databases from the administrative proceedings of professional association (Councils and Labour unions).

- Personnel working in the National Health Service (mainland, not including the islands of Azores and Madeira).

- Comparison of data in temporal trends is possible only for national aggregated data.

- The legal imperative of providing the information exists for all the enterprises but the practice is that the public ones do not perform this duty regularly.

Remuneration 
Table 3 Information sources: characteristics and limitations (Continued)

\begin{tabular}{ll}
\hline $\begin{array}{l}\text { Personnel list from all the enterprises with } \\
\text { workers (Quadro de pessoal) }\end{array}$ & $\begin{array}{l}\text { Remunerated number of hours by } \\
\text { month, normal and supplementary } \\
\text { hours }\end{array}$ \\
$\begin{array}{ll}\text { Portuguese Foreigners and Border Affairs } \\
\text { Department (Serviço de Estrangeiros }\end{array}$ & $\begin{array}{l}\text { Nationality } \\
\text { e Fronteiras) }\end{array}$ \\
$\begin{array}{l}\text { of living at the moment of request of } \\
\text { residency }\end{array}$ \\
Request of residency in Portugal & Age, sex \\
& Level of education
\end{tabular}

- Information on foreigners; the declared profession maybe different from that the person had on its country of origin. evolution of number of contracted over time); (2) reasons for mobility; (3) reasons for hiring foreign professionals; (4) consequences of mobility (for the organization, for the country, for the specific region); and (5) incentives: local and organization level incentive policies to stimulate recruitment. The interviews were conducted during December 2010 and January 2011. They were recorded and summarized according to thematic areas for analysis purposes.

\section{Results}

All pre-selected organizations in Portugal responded (Table 4) and four in Spain (Hospital of Santisima Trinidad, Salamanca; Sanatorio of Santa María, Pontevedra; Juan Ramón Jimenez Hospital, Huelva; Miguel Dominguez Hospital, Pontevedra). No response was obtained from the other nine Spanish hospitals, even after repeated contacts by telephone. These hospitals are general district hospitals, which do not offer care in some specialty areas such as cardiothoracic surgery or neurosurgery. In Portugal, this type of specialized care is provided in central hospitals located in the metropolitan areas of Lisbon, Oporto, and Coimbra.

Mobility was mainly of Spanish physicians coming to Portugal and of Portuguese nurses going to Spain.
Tables summarizing the findings are provided as Additional file 1.

\section{Spanish physicians in Portugal \\ Profile}

Interviews in Portugal indicate that Spanish physicians who cross the border are a mix of general practitioners and specialists. Many work in emergency departments, as these are more likely to have unfilled positions. The Nordeste Hospital Centre reported 18 Spanish physicians (13\% of total), 12 in the region of Bragança and 6 in Mirandela; these included 13 specialists, three general practitioners, and two residents. The Cova da Beira Hospital Centre employed seven nurses and 12 physicians from Spain (eight specialists and four residents, $8 \%$ of total). The Norte Alentejano Local Health Unit reported 44 physicians (23\% of total); 19 (17 specialists and two residents) were working in the Hospital and the others (23 general practitioners and two residents) in health centers. Further south, the Baixo Alentejo Local Health Unit reported 29 Spanish physicians (14\% of total), including 20 internists and general practitioners and nine residents. Most, though not all lived in Portugal; those crossing the border and returning home were usually working in emergency services.

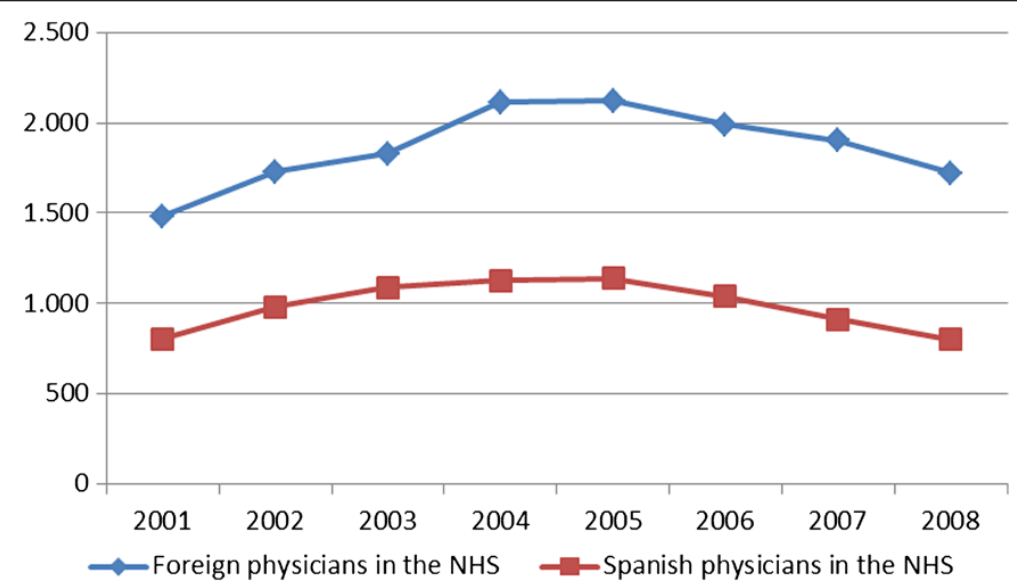

Figure 1 Total number of foreign and Spanish physicians in NHS, Portugal, 2001-2008. Source: Reference number [2]. 


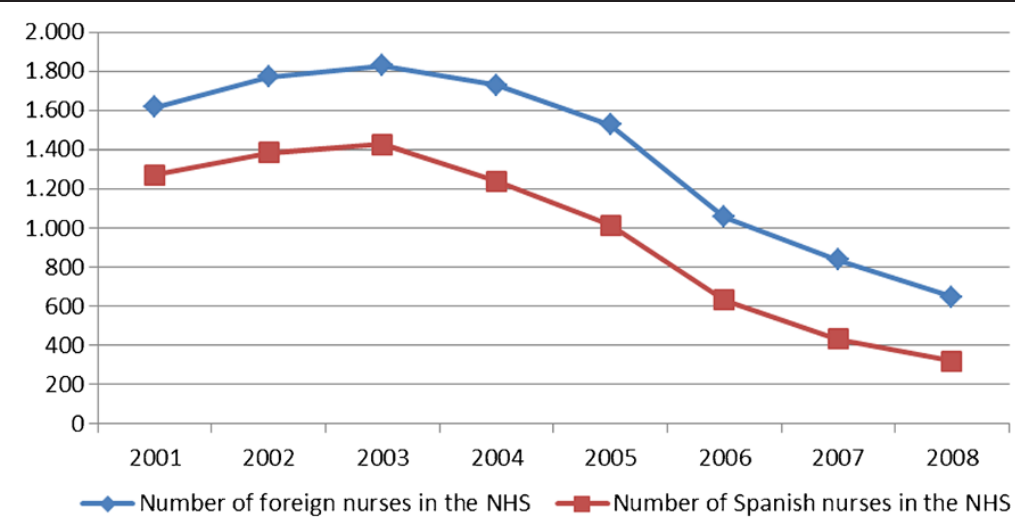

Figure 2 Total number of foreign and Spanish nurses in NHS, Portugal, 2001-2008. Source: Reference number [2].

\section{Reasons for mobility}

According to informants, there has been an immigration of Spanish physicians to Portugal for $>10$ years. Access to specialization, the availability of positions, better salaries, and better technical and organizational conditions (access to surgery rooms, team work, accredited institutions) were the main motivating factors for crossing the border. Informants welcomed this immigration which augmented the supply of specialized and primary care services.

A Portuguese hospital manager mentioned that in the past there was also a significant flow of nurses from Spain to Portugal. This trend lasted until 2008, when

Table 4 Organizations included in the survey

\begin{tabular}{|c|c|c|c|c|}
\hline \multicolumn{5}{|c|}{ Portuguese local health units and hospital Centers } \\
\hline $\begin{array}{l}\text { Regional health } \\
\text { administration }\end{array}$ & $\begin{array}{l}\text { Local health units and hospital } \\
\text { centers }\end{array}$ & Health units included & $\begin{array}{l}\text { Beds }(n) \\
(2010)\end{array}$ & $\begin{array}{l}\text { Physicians ( } n) \\
(2010)\end{array}$ \\
\hline \multirow[t]{3}{*}{ North } & \multirow[t]{3}{*}{ Nordeste Hospital Center } & Hospital of Bragança & \multirow[t]{3}{*}{435} & \multirow[t]{3}{*}{143} \\
\hline & & Hospital of Macedo de Cavaleiros & & \\
\hline & & Hospital of Mirandela & & \\
\hline \multirow[t]{2}{*}{ Center } & \multirow[t]{2}{*}{ Cova da Beira Hospital Center } & Hospital of Fundão & \multirow[t]{2}{*}{342} & \multirow[t]{2}{*}{153} \\
\hline & & Hospital of Pêro da Covilhã & & \\
\hline \multirow[t]{4}{*}{ Alentejo } & \multirow{4}{*}{$\begin{array}{l}\text { Local Health Unit of Norte } \\
\text { Alentejano }\end{array}$} & Hospital of Elvas & \multirow[t]{4}{*}{276} & \multirow[t]{4}{*}{189} \\
\hline & & Hospital of Portalegre & & \\
\hline & & $\begin{array}{l}\text { Group of health centres (ACES) of São } \\
\text { Mamede }\end{array}$ & & \\
\hline & & Group of health centres (ACES) of Caia & & \\
\hline \multirow[t]{3}{*}{ Alentejo } & \multirow[t]{3}{*}{ Local Health Unit of Baixo Alentejo } & Hospital of Beja & \multirow[t]{3}{*}{230} & \multirow[t]{3}{*}{204} \\
\hline & & Hospital of Serpa & & \\
\hline & & $\begin{array}{l}\text { Group of health centres (ACES) of Baixo } \\
\text { Alentejo }\end{array}$ & & \\
\hline \multicolumn{5}{|l|}{ Spanish hospitals } \\
\hline Autonomous Community & Hospitals & Private / public & $\begin{array}{l}\text { Beds }(n) \\
(2010)\end{array}$ & \\
\hline Castilla y León & $\begin{array}{l}\text { Hospital of Santisima Trinidad, } \\
\text { Salamanca }\end{array}$ & Private & 118 & NA \\
\hline Galicia & Sanatorio of Santa María, Pontevedra & Private & 71 & NA \\
\hline Andalucía & $\begin{array}{l}\text { Juan Ramón Jimenez Hospital, } \\
\text { Huelva }\end{array}$ & Public & 631 & NA \\
\hline Galicia & $\begin{array}{l}\text { Miguel Dominguez Hospital, } \\
\text { Pontevedra }\end{array}$ & Private & 138 & NA \\
\hline
\end{tabular}

Note: Total Portuguese NHS capacity: 20,273 beds [19]; Total beds available in Spain, public and private sector: 160,981 [8]. 
reforms which improved working conditions in Spain contributed to reversing the flow.

There are no incentives in place to attract Spanish physicians, but the possibility of topping up their salary income with extra hours in the emergency room is said to be a factor of attraction. Spanish professionals are also said to seek job opportunities in Portugal also for its perceived good living conditions.

\section{Reasons for hiring}

Spanish professionals are well considered and received in Portugal. They have been an important pool of resources to help meet the demand for services in border regions, which are considered remote and isolated by Portuguese professionals.

Informants expressed high levels of satisfaction with the work of Spanish physicians though they noted the potential negative impact of language differences on the doctorpatient relationship, and the difficulty to harmonize titles and degrees (an issue which is disappearing with the implementation of the Bologna norms). The latter creates problems in assigning staff to a specific professional cadre, and at times creates situations in which persons with similar professional profiles and occupying the same position, receive different salaries.

\section{Portuguese nurses in Spain \\ Profile}

In Spain, at the time of interviews, two nurses from Portugal worked at the Hospital General de la Santisima Trinidad in Salamanca, 12 at the Sanatorio of Santa Maria in Pontevedra, and one at Juan Ramón Jimenez Hospital in Huelva intermittently. The Miguel Dominguez Hospital in Pontevedra started to recruit Portuguese nurses in 2007, and had hired 23 since then, who stayed for periods of between 1 and 2 years.

There were no reports of Portuguese physicians working in these organizations in Spain.

\section{Reasons for mobility}

Portuguese nurses look for better working conditions, or simply a job, as there is unemployment and underemployment of nurses in their country. Informants indicated that Portuguese nurses were basically attracted by the availability of positions and that they were sought after for their good qualifications and positive attitudes towards work.

\section{Reasons for hiring}

Spanish interviewees reported that since 2008 there has been an increase of Portuguese nurses going to Spain for periods of 1 or 2 years, but no specific reasons were implied for hiring Portuguese nurses besides the need to respond to the sporadic demand.
There was no report of incentive policies.

No consequences were reported. In Spanish interviewees' opinion, Portuguese nurses are well considered and recognized as equals by their Spanish hosts in terms of professionalism and qualifications.

In general, the main reasons that bring physicians from Spain to seek work in Portugal and nurses from Portugal to go to Spain are similar. The main pull factor for professional groups is job opportunities, and for physicians, the possibility of doing a residency and access to better learning opportunities and salaries are also factors of attraction (Figure 3).

\section{Discussion}

This was a first attempt to characterize the mobility of health professionals across the border of the two countries. The study was conducted from Portugal and from a Portuguese perspective. Further studies with a Spanish counterpart would most certainly constitute an added value to the knowledge on cross-border mobility between the two countries.

The data obtained is not accessible through information publicly available by the Ministry of Health, Regional Health Administrations or the organizations themselves. The design of the study allowed the authors to complete it in a context of time and budget constrains (the study was performed as part of the European Union funded project 'MoHProf - Mobility of Health Professionals' [22]) and to obtain new data and perceptions.

The results have to be interpreted in light of limitations relative to the number of interviewees (one per organization) and to the absence of validation against the organizations' registries. Also, the limited number of Spanish respondents (four out of 13 eligible hospitals) means that only a partial picture of the phenomenon of cross-border mobility is available.

The 103 physicians identified as working along the border in Portugal represented about 15\% of Spanish physicians working in the Portuguese NHS (Table 1) and $15 \%$ of physicians in the organizations surveyed [19], which themselves accounted for $6 \%$ of the total bed capacity of the NHS (Table 4). This is not quantitatively large, but in isolated regions of a small country like Portugal, they may have a significant impact on access to services and thereby have important policy implications.

\section{From receiving to sending country}

Interviews conducted with informants from professional councils and trade unions in a separate study and statistical data on foreign health workers in Portugal suggest that the country evolved from receiving foreign health professionals, mainly from Spain and to a lesser extent from the Portuguese-speaking African Countries (PALOPs) and 


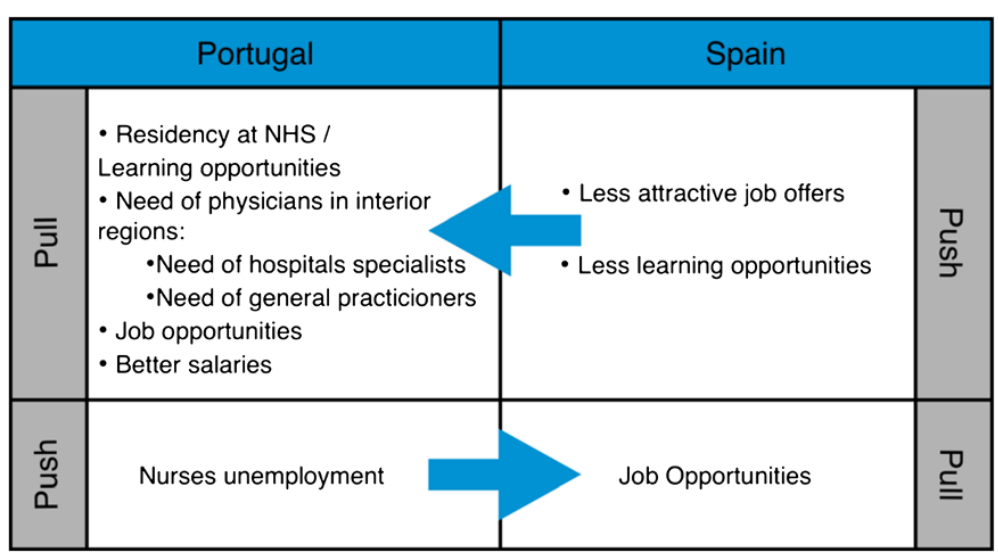

Figure 3 Summary of push and pull mobility factors.

Brazil, to sending professionals to other countries [3,22]. Unemployment, precarious employment, and the difficulty to access specialty training were the main reasons for Spanish physicians to come to Portugal. The number of unemployed physicians in Spain was estimated at 24,000 physicians (22\% total) in 1999 [23]. Emigration was estimated at 900 physicians per year between 2002 and 2006 $[10,24]$, with the USA [10], Portugal, and United Kingdom $[24,25]$ as the main destinations. Access to postgraduate specialty training was limited as the number of candidates was higher than available positions in the 1990s [26,27]. Portugal became an option for those unable to access specialty training [26-28]. The opening of positions in the public sector in Spain from 2008 onwards triggered the return of physicians.

Unemployment was the main reason for Portuguese nurses to go to Spain. The Portuguese Nursing Council estimated, in November 2012, that $20 \%$ of total nurses are unemployed or underemployed [29]. The time between the end of their studies and their first job has increased in the last 3 years. In 2009, 29.7\% of them waited 3 months to start their professional activity. In 2010 and 2011 the mode was 3 to 6 months $(29.1 \%$ in 2010 and $28 \%$ in 2011) [30]. Between January and October 2012, the Nursing Council received 1,035 requests for certificates of qualification, a document needed to work in a foreign country [29].

Although one interviewee stated that the flow from Spanish nurses to Portugal has decreased after 2008, NHS data (Figure 2 and Table 2) show a trend to decrease starting in 2003. Also for physicians (Figure 1 and Table 1) this trend started before, in 2005. Previous work on physician's geographical distribution (in 2008) had showed that being Spanish increased the odds of being based outside the Lisbon and Oporto metropolitan areas [31]. This might indicate that Spanish physicians working along the border are not returning to Spain at the same pace as those working in the biggest urban areas.

\section{Cross-border mobility impact}

Cross-border mobility impacts not only on individual health workers, but also on how health services are organized, planned, and delivered, as well as on their quality and efficiency. Like most healthcare systems, those of Portugal and Spain are challenged by workforce imbalances [32]. This is the case when the labor market cannot absorb professionals willing to work or when working conditions and career development opportunities are not seen as satisfactory. This may trigger various types of mobility: within the healthcare system from one type of job or of organization to another one, movement between regions, emigration, or even exit of the health sector. Mobility along the borders of neighboring countries is an attractive option, particularly when there are cultural affinities and when it allows maintaining close links with the country of origin, like is the case when a professional works in another country but continues living in his own. For health organizations, access to a foreign workforce close by can be seen as an opportunity to expand their recruitment area. Two recent studies $[33,34]$ have documented trends similar to those observed in Portugal and Spain; mobility along the borders of Austria and Hungary, Belgium and France, Belgium and the Netherlands, France and Switzerland, are examples. In our study, key informants stated that the benefits of employing professionals from across the border were much greater than the problems that they may entail, such as language differences or the difficulty to harmonize titles and degrees.

\section{The situation after 2011}

The interviews were conducted at the end of 2010 and beginning of 2011. More recent developments show that Spain and Portugal's health sector had to bear the consequences of the economic crisis. Both countries have applied austerity measures that have greatly affected the health sector. 
In the case of Portugal, there has been budget and personnel reduction of public hospitals [35], doubling of user fees (applicable to households above a certain level), cuts in reimbursement of medicines, and exclusion of services from insurance coverage [36].

Efforts to achieve fiscal balance have also affected both countries workforce, including salary cuts and freezing of promotions and a reduction of personnel replacement rates [37,38]. In Portugal, public sector health professionals' salaries have become less competitive with private sector's ones, which has stimulated transfers to that sector [39]. In Spain, surgical and clinical activities also suffered a significant reduction causing an increase of workload for health professionals (mostly of nurses) [38].

In general, data on health workers employed in public services do not show reduction in total numbers neither in Portugal nor in Spain [40]. Nonetheless, there are reports of mobility of Spanish and Portuguese health workers to the UK, especially from nurses [41]. There is also some new evidence, although not official, of health professionals going to Latin America as an alternative to European Union countries. There are no signs that the economic crisis will end soon in neither country, and there is a need to monitor the further consequences on the mobility of its health workforce, which at present no mechanism is set to do.

\section{The regulation of cross-border mobility}

The responsibility for planning and regulating the health workforce in Portugal is shared between the Ministries of Health and of Education and Professional Councils. There is no explicit policy or formal strategic plan for the development of the health workforce in Portugal, even though this has been identified as a need [13]. The National Health Plan 2004-2010 recommended the development of a human resources for health plan, but no steps were taken in that direction. A position paper commissioned in preparation of the NHP 2011-2016 proposed a strategic framework, including objectives for the 2011-16 period to be discussed by stakeholders and validated by further studies [11]. The discussion has yet to take place.

In Spain, each regional government usually has their functions regarding health divided between a health department and the regional health service. The health department is responsible for regulation and strategic planning, while the regional health service is responsible for operational planning, management of the services network, and coordination of healthcare provision.

The health system also draws on the input of a number of other ministries; in the case of human resources regulation, the Ministry of Education, is responsible for the regulation of health professionals' undergraduate training and, in association with the Ministry of Health and Social Policy, of postgraduate training and human resources planning.

In both countries, the main regulatory mechanisms of physician's numbers are the numerus clausus and the exam to access postgraduate specialty training. In Spain, in spite of unemployment and emigration of physicians, there are claims that there is a deficit of physicians $[10,24,42,43]$. In Portugal, the numerus clausus for entry into medicine has fluctuated from 805 in 1979 to 272 in 1984, and then gradually increasing up to 1,400 in 2007 [44] and to 1,517 in 2012 [45]. The basis on which the numerus clausus and the number of specialty places are established are not explicit. There is an unmet demand for medical training which brings unsuccessful candidates to seek training opportunities abroad. An estimated 1,300 young Portuguese study medicine in Spain, Hungary, the Czech Republic, Slovakia, among other countries [46]. As in Spain, there is no consensus on whether there are enough, too few or too many physicians in the country. The absence of strategic thinking and planning results in a reactive policy of successive decreases and increases of numerus clausus and places for specialty training.

In Portugal, there is no policy to attract national physicians and nurses to regions of the interior. In fact, the Ministry of Health has opted for recruiting foreign health workers through bilateral agreements with Latin American countries, starting with Uruguay, and then with Cuba, Colombia, and Costa Rica, to fill positions in isolated or remote areas. This ad hoc strategy may be linked to the fact that Portugal's health labor market is no longer attractive for its own professionals as indicates the success of recruitment agencies offering more attractive job opportunities to work in richer European countries and in places as far like the Gulf States and Australia [47].

\section{Conclusion}

The present study explored the mobility trends along the borders between Portugal and Spain to understand better the motives for which professionals decide to work on the other side of the frontier. Trends have been of Spanish physicians to Portugal and of Portuguese nurses to Spain. The number of professionals involved is small, but the impact on health organizations along the borders is important. The motives for crossing the border are mostly related to greater availability of work in the destination country.

In the European Union, there is freedom of movement of workers, and Member States that are geographically contiguous need to take into account as they plan their workforce the possibility that health professionals may decide to cross their borders for work. Portugal only has borders with Spain, with which it has some cultural affinities, which makes migration easier. To our knowledge, no 
national (or regional in the case of Spain) policy exists to 'manage' these flows. Key informants did not even see the need for such policy and seemed satisfied with the current situation. This not to say that it is not needed when the whole health workforce and health system is considered; for instance, migrant professionals are a gain for the receiving country, but a loss of investment for the sending one. When they reach a significant level, migratory flows are a symptom of labor market deficiencies and of poor planning. The question of the need or opportunity for governments to intervene is raised and harmonization of policies between neighboring countries may be opportune. Whether this will happen depends on the political willingness to address health workforce issues, such as that of mobility. To our knowledge, neither in Portugal or Spain there is an explicit health workforce policy and any form of monitoring and analysing mobility trends, such as exits of health professionals from the health sector or from the country. In that sense, the issue of managing the consequences of cross-border mobility is as much political as it is technical.

\section{Additional file}

Additional file 1: Table S1. Interviews in Portugal.

\section{Competing interests}

The authors declare no competing interests.

\section{Authors' contributions}

$C L, C C$, and GD designed the study and wrote the paper; $C L$ and $C C$ conducted interviews and analyzed data. All authors read and approved the final manuscript.

\section{Authors' information}

Claudia Leone, International Public Health and Biostatistics Unit, Center for Malaria and other Tropical Diseases and WHO Collaborating Center for Health Workforce Policy and Planning, Instituto de Higiene e Medicina Tropical, Lisbon.

Cláudia Conceição,School of Health Sciences, University of Minho. Gilles Dussault, International Public Health and Biostatistics Unit, Center for Malaria and other Tropical Diseases and WHO Collaborating Center for Health Workforce Policy and Planning, Instituto de Higiene e Medicina Tropical, Lisbon.

\section{Acknowledgements}

The study was conducted in the context of the project 'MohProf, Mobility of health professionals', Financed by the EC 7th Framework program of DG Research. Grant agreement No.: Health-F2-2008- 223049.

The authors are grateful to interviewees for their collaboration.

\section{Author details}

${ }^{1}$ Institute of Hygiene and Tropical Medicine, Nova University, Lisbon, Portugal. ' 2 ife and Health Sciences Research Institute (ICVS), School of Health Sciences, University of Minho, Campus de Gualtar, 4710-057 Braga, Portugal.

${ }^{3}$ ICVS/3B's - PT Government Associate Laboratory, Braga/Guimarães, Portugal.

Received: 19 February 2013 Accepted: 14 July 2013

Published: 31 July 2013

\section{References}

1. Barros P, Machado SR, Simões J: Portugal: health system review. Health Syst Transit 2011, 13:1-156.
2. Administração Central do Sistema de Saúde: Recursos Humanos Estrangeiros no Ministério da Saúde - Evolução 2001/2008. [Foreign Human Resources for Health Evolution 2001/2008.]. Lisboa: Administração Central do Sistema de Saúde; 2010. http://www.acss.min-saude.pt/Portals/0/Relat_RHE_Actualização2008.pdf.

3. Ribeiro JS, Conceição C, Pereira J, Leone C, Mendonça P, Temido M, Pacheco CV, Dussault G: Health professionals moving to... and from Portugal. Health Policy 2013, S0168-8510(13):00134-00136.

4. Jornal de Noticias: Médicos em Portugal [Foreign doctors in Portugal]. http:// www.jn.pt/multimedia/infografia970.aspx?content_id=179419.

5. Ferrinho P, Hipólito F: Imigração médica e estratégia de saúde em Portugal [Physicians immigration and health strategy in Portugal]. Janus 2009, 12:76-77.

6. Administração Central do Sistema de Saúde: Serviço Nacional de Saúde. Relatório e Contas 2010 [National Health Service 2010 report]. http://www. acss.min-saude.pt/Portals/0/Relat\%C3\%B3rio\%20e\%20Contas\%20do\%20SNS \%202010.pdf.

7. Administração Central do Sistema de Saúde: Recursos Humanos Estrangeiros no Ministério da Saúde - Actualização 2009/2010 [Foreign human resources for health at Ministry of Health 2009/2010]. Lisboa: Administração Central do Sistema de Saúde; 2011. http://www.acss.min-saude.pt/Portals/0/ Relat_RHE_Actualiza\%C3\%A7\%C3\%A302009\%202010_APGFinal.pdf.

8. García-Armesto S, Abadía-Taira MB, Durán A, Hernández-Quevedo C, BernalDelgado E: Health system review. Health Syst Transit 2010, 12:1-295.

9. Royal Decree 1041/2009 of $29^{\text {th }}$ of June. Spain: Official State Gazette (BOE).

10. Nogales Espert A: The problem of the lack of physicians. An R Acad Nac Med (Madr) 2008, 125:59-71.

11. Dussault G, Fronteira I: Human resources for health $(H R H)$ plan component of national health plan 2011-15. Lisbon: Alto Comissariado da Saúde (Portugal); 2010. http://www.acs.min-saude.pt/pns2012-2016/files/2010/08/RHS-PT.pdf.

12. Biscaia A, Martins J, Carrolo M: The state of the health workforce in Portugal. Cah Sociol Demogr Med 2007, 47:259-273.

13. Ministry of Health: National Health Plan 2004 to 2010. Vol. I. Priorities. Lisbon: Ministry of Health; 2004.

14. Biscaia A, Conceição C, Martins J, Ferrinho P: Politique et gestion des ressources humaines dans le secteur de la sante au Portugal: controverses et problématiques actuelles. Cah Sociol Demogr Med 2003, 43:379-396.

15. Rodrigues L: Compreender os recursos humanos do Serviço Nacional de Saúde [Understanding human resources for health of the National Health System]. Lisboa: Colibri Editions; 2002.

16. OECD: Health at a Glance: Europe 2012. Paris: OECD; 2012. http://dx.doi.org/ 10.1787/9789264183896-en

17. Barber Pérez P, González López-Valcarcel B: Supply and demand of medical specialists in Spain (2008-2025). Madrid: Ministry of Health and Social Policy; 2009

18. Ministério da Saúde: Hospitais EPE: Ministry of Health. EPE Hospitals. http:// www.hospitaisepe.min-saude.pt/Hospitais_EPE/Mapa_Hospitais.

19. Grupo técnico para a Reforma Hospitalar: Relatório Final: os cidadãos no centro do sistema. Os profissionais no centro da mudança: Grupo técnico para a Reforma Hospitalar criado pelo Despacho N.o 10.601/2011 do Ministro da Saúde, publicado em Diário da República N.o 162, 2a Série, de 24 de Agosto de 2011 [Report of the technical group on Hospital reform, nominated by the Ministry of Health]. http://www.portaldasaude.pt/NR/rdonlyres/84FCFCE23C84-4ABE-8E5F-AD4DDB0B46F4/0/RelatorioGTRH_Nov2011.pdf.

20. Ministerio de Sanidad, Servicios Sociales e Igualdad. Portal estadístico del SNS: Spanish Ministry of Health. NHS statistical portal. http://www.msc.es/ca/ estadisticas/microdatos.do.

21. Catálogo Nacional de Hospitales de España: Spain's National Hospital Catalogue. http://www.hospitalandia.com.

22. Conceição C, Ribeiro JS, Pereira J, Dussault G: Portugal: Mobility of Health Professionals. Lisboa: Associação para o Desenvolvimento da Medicina Tropical e Instituto de Higiene e Medicina Tropical, Universidade Nova de Lisboa; 2011. http://www.mohprof.eu/LIVE/DATA/National_reports/ national_report_Portugal.pdf.

23. Bosch X: Too many physicians trained in Spain. JAMA 1999, 282:1025-1026.

24. García MÁ, Amaya C: Is there a need for more medical doctors in Spain? Ars MedicaRevista de Humanidades 2007, 2:152-170.

25. Villanueva T: Spain must tackle uneven distribution of its doctors, report says. BMJ $2008,336: 241$.

26. Escuela Andaluza de Salud Pública: Demografía sanitaria en Andalucía: Diseño e implementación de una estrategia de planificación regional sobre la oferta y demanda de profesionales sanitarios. [Health Demography in 
Andalucia: Design and implementation of a regional planning strategy over the supply and demand of health professionals]. Sevilla: Consejería de Salud, Junta de Andalucía [s.d.]; 2007.

27. Santana P: The experience of Spanish trainees in the UK (1986-1996): a tragedy in four acts. Hosp Med 1999, 60:58-61.

28. Administração Central do Sistema de Saúde e Universidade de Coimbra: Estudo das necessidades previsionais de Recursos Humanos em Saúde Médicos. Relatório Final. Abril, 2009 [Estimation on health workforce needs physicians. Final report April 2009]. Lisboa: Administração Central do Sistema de Saúde; 2009.

29. Jornal Publico: More than 20\% of nurses are unemployed 23/11/2012. http:// p3.publico.pt/actualidade/economia/5547/mais-de-20-dos-enfermeiros-estano-desemprego.

30. Fernandes R, Martins B, Maurício B, Matos D, Ferrera D, Afonso L, Goveia M, Goulart MJ, Dias P, Melo P, Silva P, Morgado T: Situação profissional dos jovens enfermeiros em Portugal 2011 [Study of the professional situation of young nurses in Portugal]. Lisboa: Ordem dos enfermeiros; 2011. http://www. ordemenfermeiros.pt/documentosoficiais/Documents/ SituacaoProfissionalJovensEnfermeiros2011.pdf.

31. Russo G, Ferrinho P, De Sousa B, Conceição C: What influences national and foreign physicians' geographic distribution? An analysis of medical doctors' residence location in Portugal. Human Resources for Health 2012, 10:12.

32. Kuhlmann E, Batenburg R, Groenewegen PP, Larsen C: Bringing a European perspective to the health human resources debate: A scoping study. Health Policy 2013, 110:6-13. http://dx.doi.org/10.1016/j.healthpol.2012.11.002.

33. Wismar M, Maier CB, Glinos IA, Dussault G, Figueras J: Health professional mobility and health systems: evidence from 17 European countries. Copenhagen: WHO Regional Office for Europe on behalf of the European Observatory on Health Systems and Policies; 2011.

34. Tjadens F, Weilandt C, Eckert J: Mobility of Health Professionals: Health Systems, Work Conditions, Patterns of Health, Workers' Mobility and Implications for Policy Makers. Berlin Heidelberg: Springer-Verlag; 2013.

35. European Federation of Nurses Associations: Caring in crisis: the impact of the financial crisis on nurses and nursing. A comparative overview of 34 European countries. Brussels: European Federation of Nurses Associations; 2012. http://www.efnweb.be/wp-content/uploads/2012/05/EFN-Report-onthe-Impact-of-the-Financial-Crisis-on-Nurses-and-Nursing-January-20122.pdf.

36. Mladovsky P, Srivastava D, Cylus J, Karanikolos M, Evetovits T, Thomson S, McKee M: Health policy responses to the financial crisis in Europe. Policy summary 5. Copenhagen: World Health Organization on behalf of the European Observatory on Health Systems and Policies; 2012.

37. HOPE - European Hospital and Healthcare Federation: The impact of the crisis on hospitals, healthcare services, healthcare professionals and patients. evidence from HOPE. 2011. http://www.epha.org/a/5111.

38. Sanitaria 2000. Revista Redaccion Médica: Aumenta la emigración médica en España antes los recortes.30 de julio de 2012 [Medical migration increases in Spain due to budget cuts]. http://www.redaccionmedica.es/noticia/elmedico-espanol-huye-de-los-recortes-sanitarios-6133.

39. OPSS- Observatório Português dos Sistemas de Saúde: Relatório Primavera 2012. Crise e Saúde: Um país em Sofrimento. [Portuguese observatory on health systems. Spring report: Crises and health: a suffering country]. Lisboa: OPSS; 2012; 2012.

40. Dussault G, Buchan J: The economic crisis in the EU: impact on health workforce mobility. In Health professional mobility in a changing Europe: new dynamics, mobile individuals and policy responses. Edited by Buchan J, Bremner J, Glinos I, Wismar M. Brussels: European Observatory on Health Systems and Policies. in press.

41. Buchan J, Seccombe I: Overstretched. Under-resourced. The UK nursing labour market review 2012. London: Royal College of Nursing; 2012.

42. López-Valcárcel BG, Pérez PB: Los recursos humanos y sus desequilibrios mitigables [Human resources and related imbalances, which it is possible to mitigate]. Gac Sanit 2006, 20(Suppl 1):103-109.

43. Gérvas J, Bonis J, Seminario de Innovación en Atención Primaria: El debate profesional acerca de la escasez de médicos [Professional debate on shortage of physicians]. Rev Esp Salud Publica 2007, 2008(82):627-635.

44. Grupo de Missão: Resolução do Conselho de Ministros n. 140/98, de 4 de Dezembro: Resolução do Conselho de Ministros n.o 140/98, de 4 de Dezembro: Plano estratégico para a formação nas áreas da saúde. Lisboa: Dezembro de 2001 [Strategic plan for the education in health áreas. December 2001]; 2001.
45. Direção Geral do Ensino Superior [Higher Education General Directorate]: Dados finais dos concursos 2011 e 1012 [Final data for 2011 and 1012 courses Database]. http://www.dges.mctes.pt/DGES/pt/Estudantes/Acesso/ Estatisticas/EstudosEstatisticas/cna-dadosfinais-20112012_20122013.htm.

46. Conceição C, Ribeiro JS, Pereira J: Health professional Mobility in Portugal. Hospital do futuro 2011, 14:43-46.

47. OECD: Public expenditure on health, Health: Key Tables from OECD, No. 3. Paris: OECD; 2013. doi:10.1787/hlthxp-pub-table-2013-1-en.

doi:10.1186/1478-4491-11-36

Cite this article as: Leone et al:: Trends of cross-border mobility of physicians and nurses between Portugal and Spain. Human Resources for Health 2013 11:36.

\section{Submit your next manuscript to BioMed Central and take full advantage of:}

- Convenient online submission

- Thorough peer review

- No space constraints or color figure charges

- Immediate publication on acceptance

- Inclusion in PubMed, CAS, Scopus and Google Scholar

- Research which is freely available for redistribution

Submit your manuscript at www.biomedcentral.com/submit
C) Biomed Central 